\section{living with No-growth}

THERE has been a remarkable transition in the past few weeks from a situation in which energy was a nagging middle term concern, to be dealt with by orderly readjustment of priorities, to that which prevails now, in which fuel shortages are commonplace and even desperate measures may be ineffectual. The consequences of this sudden crisis can barely be guessed yet, because although it is indisputable that oil prices in the future will be much higher, it is an open question whether oil will ever flow as freely again. The view from Britain is bound to be coloured by the simultaneous progressive seizing up of the electricity and coal industries and the railways on account of industrial action. Nevertheless the situation can hardly be said to be other than gloomy in any industrialised society.

The cutback in oil supplies has some advantages to it. At a stroke, it highlights the extraordinary way in which we have been acquiring energy cheaply and squandering it. Certainly no government would have been able to impose restrictions on home heating, office lighting, high speed driving, flying half-empty aircraft and sundry other current affectations in the absence of such a visible crisis. Yet now there is little complaint at such impositions and no doubt that such moderation in our habits will become part of our way of life.

Further lessons in restraint should also be sinking in. Military ventures by countries less than self-sufficient in oil and capable of supplying the huge increase in demand that war generates will be out of the question. This may not hold back the Soviet Union, but the United States, which has allowed itself to be lured by the deception of cheap energy into becoming an importer of fuel despite its huge resources, must temper its military policies unless it wants the North-east to freeze to death.

It is necessary to think beyond the immediate problems, however, and there is little doubt that the impact on science of the discontinuous change in the economic situation will be very serious. Economic growth for 1974 has been abandoned, implicitly if not explicitly, in many countries. A reduction in oil supplies, even temporary, makes even a stationary gross national product a difficult target to reach.

For a long time economists have debated the pros and cons of a no-growth economy and the arguments in favour of such a concept have become more appealing, if not yet compelling, in recent years. The Fall 1973 issue of Daedalus is devoted to a scholarly debate on the subject, which makes for interesting reading now that no-growth is thrust upon us, rather than, as even its keenest advocates would have, being introduced over a space of years.

Growth, as Harvey Brooks puts it, "provides opportunities for talented or ambitious people to rise in social status and income without depriving others of status". If there is no growth then nobody can prosper without another faltering and there is palpably a great social need to ensure that if there is to be any income redistribution it is such that those at the bottom gain at the expense of those at the top. But what is true for individuals is also true for institutions. Any spell of no-growth will at best freeze government spending and may well reduce it substantially, as such spending is an easily manipulated economic tool. It is very difficult to see how science budgets strongly dependent on government funds could remain intact under these circumstances. No-growth could never produce an Apollo programme, indeed Mancur Olson goes even further, "there would be few if any frontiers .... in a no-growth society".

The problem is not purely a British one, although Britain in its present predicament would feel the effects of an unplanned stoppage of growth most keenly and most quickly. All industrial societies with growth targets that now have to be lowered will experience severe conflicts over priorities, and science is likely to come out the loser, especially when in competition with schools and hospitals for the same money. Such a situation could presumably render a large number of scientists redundant. A preferable alternative is that governments will see that even if they cannot hold the line on pure science they can justifiably switch scientific manpower to social needs programmes.

If the situation is not good in industrial countries, it is little short of appalling in the developing world. Even for those countries that the producers exempt from oil cuts, the rise in the price of oil must do damage to economies at a time when the prospects for improved aid from richer countries are negligible. It is not out of place to question whether science and scientific institutions can survive at all in developing countries.

\section{Years Ago}

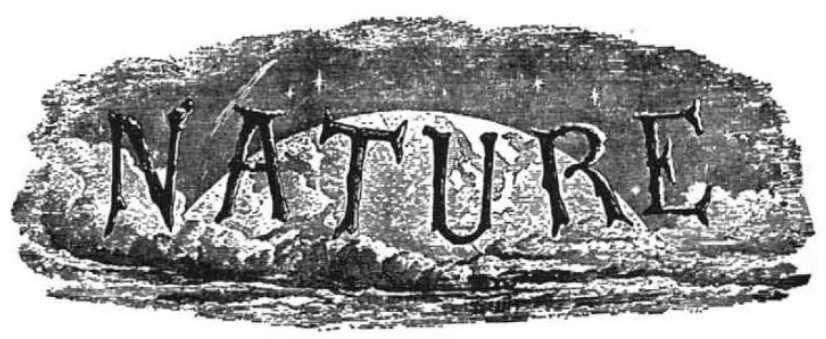

THE Council of the Socitty of Arts have given notice of their intention to provide a short course of lectures suitable for a juvenile auditory during the Christmas holidays. For this purpose arrangements have been made with Mr. Frank Buckland, iN.A., Her Majesty's Iespector of Salmon Fisheries, to deliver two lectures "On the Structure and Habits of Beasts, Birds, and Fishes, as shuwing Beauly and Design," on Friday, January 2 , and Friday, January 9, at 8 P.M. The lectures will be illustrated by specimens. It is intended to make every effort to obtain an entirely juvenile audience, and the notice in the Society's Fournal impresses strongly upon the members the fact that only children, not adulis, are wanted.

From Nature, 9, 151, December 25, 1873. 